\begin{tabular}{|c|c|c|c|c|}
\hline Caucasian Journal of Science & $\begin{array}{c}\text { ISSN: } 2148-6840 \\
\text { Year: } 2021 \\
\text { https://doi.org/10.48138/cjo.1037727 }\end{array}$ \\
\hline
\end{tabular}

\title{
Naphthoquinones from Onosma: Molecular Mechanisms of Action in the Treatment and Prevention of COVID-19
}

\author{
Namık KILINÇ ${ }^{1}$
}

Makalenin alanı: Sağlık

\begin{tabular}{|c|c|}
\hline Mak & $\mathrm{Oz}$ \\
\hline Geliş & \multirow{9}{*}{$\begin{array}{l}\text { Şiddetli akut solunum sendromu koronavirüs 2'nin (SARS-CoV-2) neden olduğu COVID- } \\
19 \text {, ilk olarak Aralık } 2019 \text { 'da Çin'in Vuhan kentinde tespit edildi. Şu anda virüs için etkili } \\
\text { bir tedavi veya bağışılama yok ve yüksek ölüm oranıyla hızla yayılıyor. Hem viral } \\
\text { replikasyonun hem de transkripsiyonun başlatılımasında rol oynayan çok önemli bir } \\
\text { CoV enzimi olan COVID-19 ana proteazı (Mpro), araştırmacılar için çekici bir hedeftir. } \\
\text { SARS-CoV-2'nin neden olduğu COVID-19'un erken aşamalarını tedavi etmek için acilen } \\
\text { yeni terapötiklere ihtiyaçvardır. Bu nedenle, potansiyel COVID-19 Mpro inhibitörlerini } \\
\text { bulmak için Onosma cinsinden naftokinonlar, Mpro enzimi üzerindeki olası etkilerini } \\
\text { bulmak için tarandı. Bu çalışmada, mevcut doğal ürün veritabanlarından SARS-CoV-2 } \\
\text { Mpro'nun potansiyel inhibitörlerini ortaya çıkarmak için moleküler yerleştirme ve } \\
\text { MM-GBSA dahil olmak üzere bir dizi hesaplama yaklaşımı kullandık. Bulgularımıza göre } \\
\text { deoksishikonin, 3-hidroksi-izovaleril shikonin, propionil shikonin ve asetil shikonin } \\
\text { moleküllerinin Mpro enzimine yüksek bağlanma afiniteleri vardır. Ayrıca diğer shikonin } \\
\text { bileşiklerinin anti-Mpro enzim aktivitesine sahip olduğu gözlendi. Yerleştirme } \\
\text { simülasyonları ve moleküler mekanik, shikonin türevlerinin etkili anti-SARS-CoV-2 } \\
\text { bileşikleri olabileceğini düşündürmektedir. }\end{array}$} \\
\hline & \\
\hline Kabu & \\
\hline & \\
\hline & \\
\hline & \\
\hline & \\
\hline & \\
\hline " & \\
\hline
\end{tabular}

\begin{tabular}{|c|c|}
\hline Art & \multirow{11}{*}{$\begin{array}{l}\text { COVID-19, which is caused by the severe acute respiratory syndrome coronavirus } 2 \\
\text { (SARS-CoV-2), was first detected in December } 2019 \text { in Wuhan, China. There is currently } \\
\text { no effective treatment or immunization for the virus, and it is spreading rapidly with a } \\
\text { high mortality rate. As a crucial CoV enzyme involved in initiating both viral replication } \\
\text { and transcription, the COVID-19 main protease (Mpro) is an appealing target for } \\
\text { researchers. Novel therapeutics are urgently required to treat the early stages of COVID- } \\
19 \text { caused by SARS-CoV-2. Therefore, to find potential COVID-19 Mpro inhibitors, } \\
\text { naphthoquinones from the Onosma genus were screened to find out their possible } \\
\text { effects on the Mpro enzyme. In this study, we employed a range of computational } \\
\text { approaches, including molecular docking and MM-GBSA, to uncover potential inhibitors } \\
\text { of SARS-CoV-2 Mpro from existing natural product databases. According to our findings, } \\
\text { the molecules deoxyshikonin, 3-hydroxy-isovaleryl shikonin, propionyl shikonin, and } \\
\text { acetyl shikonin have high binding affinities for the Mpro enzyme. In addition, it was } \\
\text { observed that the other shikonin compounds have anti-Mpro enzyme activity. Docking } \\
\text { simulations and molecular mechanics suggest that shikonin derivatives might be } \\
\text { effective anti-SARS-CoV-2 compounds. }\end{array}$} \\
\hline Received & \\
\hline 17.12.2021 & \\
\hline Accepted & \\
\hline 29.12.2021 & \\
\hline Keywords & \\
\hline COV & \\
\hline Molecular docking & \\
\hline Naphthoq & \\
\hline Ono & \\
\hline Shikonin & \\
\hline
\end{tabular}

${ }^{1}$ Iğdır University Vocational School of Health Service Department of Medical Services and Techniques-lğdır; e-mail: namikkilinc@igdir.edu.tr; ORCID: 0000-0002-9102-1370 


\section{Introduction}

The coronavirus disease, which was officially designated as Covid-19 by the World Health Organization on February 11, 2020, originated in Wuhan, China, in December 2019 and has rapidly spread around the world in an epidemic manner (Lillie et al., 2020). The new coronavirus was called SARS-CoV-2, according to the International Virus Classification Commission. COVID-19 is not the first virus to be linked to a coronavirus-related severe respiratory disease (Lai et al., 2020). Coronaviruses, on the other hand, have produced three pandemic infections in the last 20 years: SARS-CoV-2, MERS-CoV, and SARS CoV (De Wit et al., 2016). COVID-19 cases have been recorded in many countries throughout the globe (Wu et al., 2020).

Coronavirus is a member of the Coronaviridae family, which is part of the Nidovirales order. Coronaviruses are a wide family of positive-sense, single-stranded RNA viruses (Yan et al., 2020). Coronaviruses have been detected in mice, poultry, swine, cattle, rats, turkeys, dogs, rabbits, horses, cats, and humans, with genomic RNA measuring 26-32 kb and being capped and polyadenylated. Coronaviruses may cause a variety of severe ailments, including gastroenteritis and respiratory tract infections (Van Der Hoek et al., 2004). Pneumonia is the most common indication and symptom of SARS-CoV-2 infection. Other symptoms include headache, shortness of breath (dyspnea), cough, chest discomfort, tiredness, diarrhea, muscular soreness, fever, anorexia, sore throat, vomiting, disorientation, and nausea. At least four comprehensive investigations on clinical and epidemiological aspects of SARS-CoV-2 infected individuals have been conducted. Fatigue, cough, and fever were reported by 96 percent, 68 percent, and 90 percent of patients, respectively, in this study (Zheng, 2020).

There is currently no treatment available for COVID-19. As a result, medicines that may suppress SARS-CoV-2 are required. The Main Protease (Mpro) is one of the main therapeutic targets for combating coronaviruses (Figure 1). Polyproteins produced by viral RNA transcription are processed by the Mpro, which is responsible for this processing in the cell (Hilgenfeld, 2014). From humans to other animals, the amino acid sequences of the Mpro of all SARS-like CoVs are substantially conserved (Ortega et al., 2020). The Mpro has a proclivity towards forming dimers (protomer A and B). Three domains can be found in protomers. An antiparallel $\beta$-barrel structure is formed by domain I (residues 8-101) and domain II (residues 102-184). A cleft between these two domains contains the substrate-binding pocket. Domain III (residues 201-303) forms an antiparallel globular cluster with five $\alpha$-helices (Jin et al., 2020). 


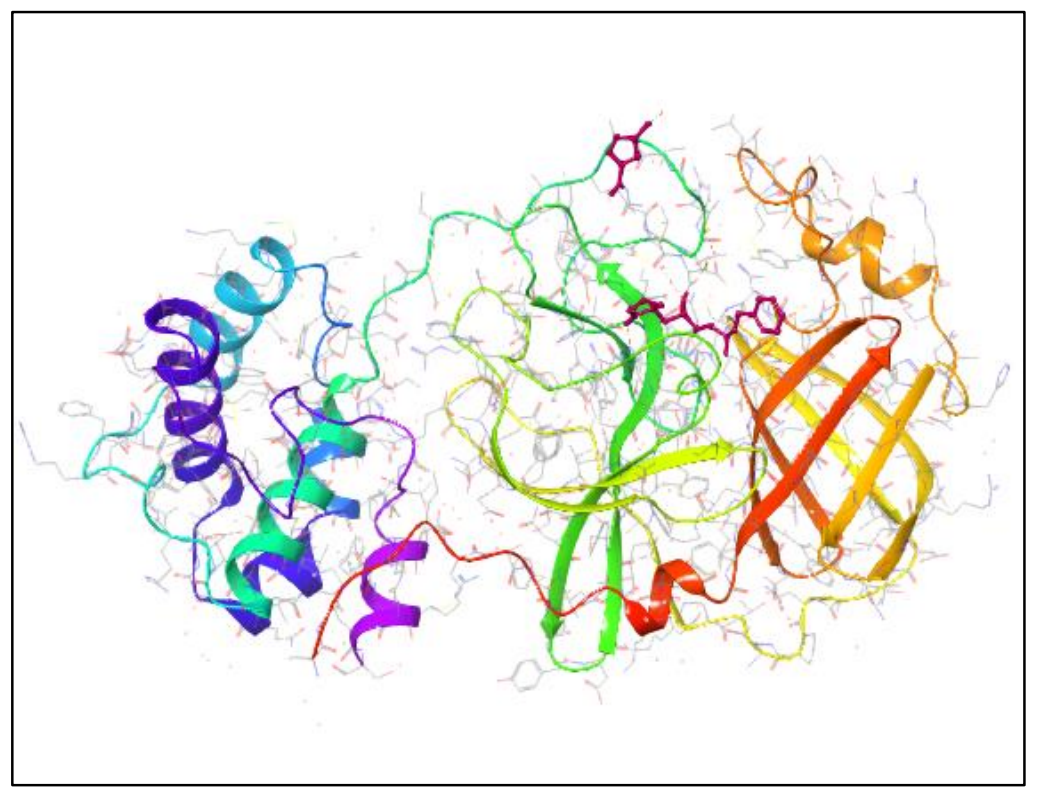

Figure 1. Crystal structure of COVID-19 Main Protease in complex with the inhibitor N3 (PDB ID: 7BQY)

More than 150 species are known to exist in the genus Onosma (Boraginaceae) (EI Shazly et al. 2003 ). In the flora of Turkey, the genus Onosma is represented by 97 species, 4 variations, and 1 hybrid species (102 taxa), 50 species and 1 variety of which are endemic, with a 50\% incidence of endemism (Binzet and Orcan, 2009). Naphthoquinones (alkannin, shikonin, and alkannin/shikonin derivatives) are found in the roots of several Onosma species (Ozgen et al., 2011; Kagramanyan and Mnatsakanyan, 1985; Sut et al., 2017; Ozgen et al., 2006). In this study, the possible inhibitory effects of naphthoquinones in the Onosma genus on the Main Protease (Mpro) enzyme, which is responsible for the replication of the coronavirus in the cell, were investigated.

\section{MATERIALS AND METHOD}

Online bibliographic sources such as Science Direct, PubMed, Web of Science, and Google Scholar were used to acquire data on Onosma naphthoquinones.

\section{Protein Preparation}

The RCSB Protein Data Bank (PDB) was used to get the X-ray crystal structure of COVID19 Main Protease (PDB code: 7BQY). The Protein Preparation Wizard of Schrödinger Molecular Modelling Suite was used to pre-process and prepare the X-ray crystal structure. Converting 
selenomethionines to methionines, assigning bond orders, filling in missing side chains and loops (if any) (using Prime), adding hydrogens to protein structures, generating het states at pH 7.0 \pm 2.0 (using Epik), creating zero-order bonds to metals and disulfide bonds, and deleting water molecules beyond 5 from het groups are all processes performed by Protein Preparation Wizard. PROPKA was used to improve $\mathrm{H}$-bond assignment at $\mathrm{pH} 7.0$ with several water sample orientations. The OPLS3e force field was used to minimize the energy of protein structures under physiological parameters.

\section{Ligand Preparation}

A ligand library including 13 shikonin derivatives from Onosma species was generated as a starting point using PubChem's 2D structures. The 2D structures of the medications favipiravir, remdesivir, and hydroxychloroquine used in covid therapy were retrieved from PubChem for comparison. Maestro's LigPrep module was used to create 2D structure drawings of all ligands to be docked into the Mpro protein, as well as 3D transformations of these structures. With the OPLS3e force field, the LigPrep module was also utilized to create potential ionization and optical isomers of ligands at physiological $\mathrm{pH}$.

\section{Possible Binding Site Identification And Grid Generation}

The main protease protein's ligand-binding sites were predicted using the Schrödinger suite's SiteMap tool. SiteMap looks for all probable binding sites on the protein surface and ranks them using the Dscore scoring function. Five potential binding sites for the main protease protein were discovered as a consequence of SiteMap. Using Maestro's Receptor Grid Generation module, a grid box of $20 \AA$ × $20 \AA$ × $20 \AA$ was formed on the best-scored binding site predicted by SiteMap.

\section{Extra Precision (XP) Docking}

Schrödinger Maestro software was used to conduct all docking simulations and visualizations of shikonin derivatives against the Mpro receptor (Schrödinger, 2020). The Glide Extra Precision (XP) docking approach was used to the top-scoring binding site previously discovered by SiteMap for a total of 13 compounds collected from Onosma species. The receptor sites are maintained rigid throughout the XP docking technique, but the ligands are permitted to move freely (Kılınç, 2021). 


\section{Binding Free Energy Calculation Using Molecular Mechanics/Generalized Born Surface Area (MM/GBSA)}

The free binding energies of the protein and ligand complexes were investigated using the MM-GBSA (Molecular Mechanics, the Generalized Born model, and Solvent Accessibility) approach. The optimum binding energy of the chosen complexes with the lowest docking score was calculated using the Prime module of Schrödinger program. The VSGB 2.0 model was used for the investigation, using an OPLS3e force field that included an implicit solvent model as well as physics-based modifications for hydrophobic interactions, $\pi-\pi$ interactions, and hydrogen bonding self-contact interactions (Genheden and Ryde, 2015).

\section{RESULTS}

Molecular docking studies using two distinct approaches were used to investigate the possible effects of 13 shikonin derivatives in Onosma species on the Mpro enzyme. To begin, the SiteMap module of Maestro was used to find the probable ligand binding sites for the Mpro enzyme (Table 1).

Table 1. Five top-scored ligand binding sites of main protease enzyme

\begin{tabular}{llllll}
\hline Name & Dscore & volume & phobic & philic & \multicolumn{1}{c}{ residues } \\
\hline Site 1 & 1,04 & 264,8 & 0,93 & 0,89 & $\begin{array}{l}\text { Chain A: } 25,26,27,41,44,49,52,54,140,141,142,145,163,164,165,166,167,168,172, \\
187,188,189,190,191,192\end{array}$ \\
\hline Site 2 & 0,81 & 249,4 & 0,40 & 1,01 & $\begin{array}{l}\text { Chain A:8,107,108,109,110,111,127,151,153, } \\
200,201,202,203,240,242,246,249,292,293, \\
294,295,298\end{array}$ \\
\hline Site 4 & 0,49 & 73,40 & 0,44 & 1,14 & $\begin{array}{l}\text { Chain A: 218,219,220,221,267,270, 271,274, } \\
275,279\end{array}$ \\
\hline Site 3 & 0,53 & 107,7 & 0,16 & 1,04 & Chain A: 15,17,18,19,31,69,70,71,97,119,120 \\
\hline Site 5 & 0,34 & 53,20 & 0,25 & 1,47 & Chain A: 3,4,5,207,282,284,288,291 \\
\hline
\end{tabular}

Using the extra precision (XP) docking methodology, thirteen naphtoquinones identified in onosma and three positive control compounds were docked to the ligand binding site defined for the target protein. All naphtoquinones were docked flexibly to the Mpro enzyme binding site. Additionally, we used the Prime MM/GBSA module to calculate the free binding energies of naphtoquinones and positive control medicines to the Mpro receptor, 
allowing us to get a better understanding of the thermodynamic factors governing their binding activities. Table 2 shows the XP docking findings and Prime MM/GBSA free binding energy results of naphtoquinones against the Mpro receptor.

Table 2. XP docking and MM-GBSA results of naphtoquinones and reference compounds against Mpro receptor

\begin{tabular}{|c|c|c|c|c|}
\hline Name & $\begin{array}{c}\text { Docking } \\
\text { score }\end{array}$ & XP GScore & $\begin{array}{c}\text { Glide } \\
\text { emodel }\end{array}$ & $\begin{array}{l}\text { MM- } \\
\text { GBSA }\end{array}$ \\
\hline Deoxyshikonin & $-7,49$ & $-7,50$ & $-38,98$ & -44.37 \\
\hline 3-hydroxy-isovaleryl shikonin & $-6,51$ & $-6,53$ & $-55,59$ & -59.02 \\
\hline Propionyl shikonin & $-5,95$ & $-5,96$ & $-48,05$ & -48.19 \\
\hline Acetyl shikonin & $-5,85$ & $-5,87$ & $-46,91$ & -45.98 \\
\hline Shikonin & $-5,65$ & $-5,66$ & $-37,94$ & -34.85 \\
\hline $\begin{array}{l}\text { 1-(5,8-dimethoxy-1,4-dioxo-1,4- } \\
\text { dihydronaphthalen-2-yl)-4- } \\
\text { methylpent-3-en-1-yl 2- } \\
\text { methylbutanoate }\end{array}$ & $-5,62$ & $-5,62$ & $-43,80$ & -39.53 \\
\hline$\beta, \beta$-Dimethylacryl shikonin & $-5,58$ & $-5,59$ & $-49,36$ & -46.93 \\
\hline Isobutyryl shikonin & $-5,51$ & $-5,52$ & $-47,83$ & -45.92 \\
\hline Isovaleryl shikonin & $-5,38$ & $-5,39$ & $-58,85$ & -44.52 \\
\hline $\begin{array}{l}\text { (E)-2-(4-hydroxy-4-methylpent-2-en- } \\
\text { 1-yl)-5,8-dimethoxynaphthalene-1,4- } \\
\text { dione }\end{array}$ & $-5,07$ & $-5,07$ & $-43,03$ & -38.00 \\
\hline 5,8-0-dimethyl deoxyshikonin & $-4,85$ & $-4,85$ & $-46,31$ & -44.95 \\
\hline 5,8-0-dimethylacetyl shikonin & $-4,59$ & $-4,60$ & $-50,34$ & -46.21 \\
\hline 5,8-dimethoxyisobutyryl shikonin & $-4,31$ & $-4,31$ & $-45,94$ & -41.34 \\
\hline Remdesivir & $-8,48$ & $-8,48$ & $-75,77$ & -68.45 \\
\hline Hydroxychloroquine & $-5,19$ & $-5,19$ & $-36,23$ & -24.86 \\
\hline Favipiravir & $-3,77$ & $-3,77$ & $-24,11$ & -18.31 \\
\hline
\end{tabular}

\section{DISCUSSION AND CONCLUSION}

The use of plants to cure diseases is a widely used practice across the globe. Ethnobotanical research forms a large part of the practice of scientists. Health care for 80 percent of the world's population still heavily depends on herbal treatments (Oladele et al., 2020). Numerous studies are showing that herbs have antibacterial, antifungal, and antiviral 
effects. Plants show these effects through phenolic compounds, secondary metabolites, and other chemicals in their content (Tada et al., 1994; Koch et al., 2008; Mukhtar et al., 2008; Tan et al., 2013; Mikaili et al., 2013). SARS, MERS, dengue, and influenza virus symptoms have been treated using plant-derived antiviral medications (Theisen and Muller, 2012; Yu et al., 2012; Zandi et al., 2012). Natural compounds originated from plants, such as flavonoids and xanthones, as well as other chemical components with antibacterial, antiviral, and antiinflammatory properties, might interact well with SARS-CoV-2 targets. As a consequence, herbal drugs containing these compounds as key ingredients might be beneficial in the treatment of SARS-CoV-2 infections.

Shikonin is a key naphthoquinone natural substance obtained from Onosma species' roots (Ozgen et al., 2011; Sut et al., 2017). Shikonin has a diverse set of pharmacological properties, including anti-cancer, anti-oxidant, antibacterial, and anti-inflammatory properties. Shikonin has been reported to have antiviral effect against the adenovirus and human immunodeficiency virus-1 (HIV-1) (Andújar et al., 2013; Chen et al., 2003). These properties of the shikonin compound have increased the interest in this compound and its derivatives. Therefore, our current study was designed considering that shikonin and its derivatives may have a potential effect on SARS-CoV-2 virus. For this purpose, the potential effects of shikonin and its derivatives on the SARS-CoV-2 Main Protease enzyme were investigated using molecular docking and molecular mechanics techniques.

Molecular docking simulations showed that the best scoring compound was Deoxyshikonin. Although deoxyshikonin scored lower than Remdesivir, it scored better than the other positive control compounds hydroxychloroquine and favipiravir. Deoxyshikonin made hydrogen bonding with amino acid residues LEU141, GLY143, GLU166, and GLN189 at the active site of the Mpro enzyme (Figure 2 and 3). In the molecular mechanical calculations for the Deoxyshikonin compound, it was determined that the free binding energy for the Mpro enzyme was $-44.37 \mathrm{kcal} / \mathrm{mol}$ (Table 2). 3-hydroxy-isovaleryl shikonin compound, another highscoring compound against SARS-CoV-2 Mpro enzyme, was found in hydrogen bond interaction with ASN142, GLU166, GLN189, and GLN19 residues in the active site of the enzyme, similar to the deoxyshikonin compound (Figure 2). The 3-hydroxy-isovaleryl shikonin compound was determined as the compound with the highest free binding energy value $(59.02 \mathrm{kcal} / \mathrm{mol})$ among the shikonin derivatives, whose possible inhibition effects against the Mpro enzyme were investigated. The free binding energies of Propionyl shikonin and Acetyl shikonin 
compounds, whose docking scores against the SARS-CoV-2 Mpro enzyme were very close to each other, were similarly close. While the propionyl shikonin compound hydrogen bonded with the amino acid residues LEU141 and GLN189, Acetyl shikonin hydrogen bonded with the residues of GLU166 and THR190 in the catalytic active site of the Mpro enzyme (Figure 2). Propionyl shikonin and Acetyl shikonin both outperformed the positive control compounds hydroxychloroquine and favipiravir. Considering the free binding energies and docking scores of these two compounds, it can be said that they have a potent affinity for the SARS-CoV-2 Mpro enzyme. Other shikonin derivatives other than the best-scoring deoxyshikonin, 3hydroxy-isovaleryl shikonin, propionyl shikonin, and acetyl shikonin compounds against Mpro enzyme also showed very high affinity for Mpro enzyme regarding their docking scores and binding free energies.

Novel therapies for treating the early stages of COVID-19 induced by SARS-CoV-2 are urgently needed. Mpro is one of the antiviral targets that might be used to treat SARS-CoV-2. Natural resources abound, which may be used to find pharmacologically important natural compounds. In this study, to find possible inhibitors of SARS-CoV-2 Mpro from existing natural product databases, we used a variety of computational techniques, including molecular docking and MM-GBSA. The molecules deoxyshikonin, 3-hydroxy-isovaleryl shikonin, propionyl shikonin, and acetyl shikonin exhibit great binding affinities for the Mpro enzyme, according to our findings. Furthermore, it was discovered that the other shikonin compounds displayed potential anti-Mpro enzyme activity. Shikonin derivatives may be strong anti-SARSCoV-2 drugs, according to docking simulations and molecular mechanics. 


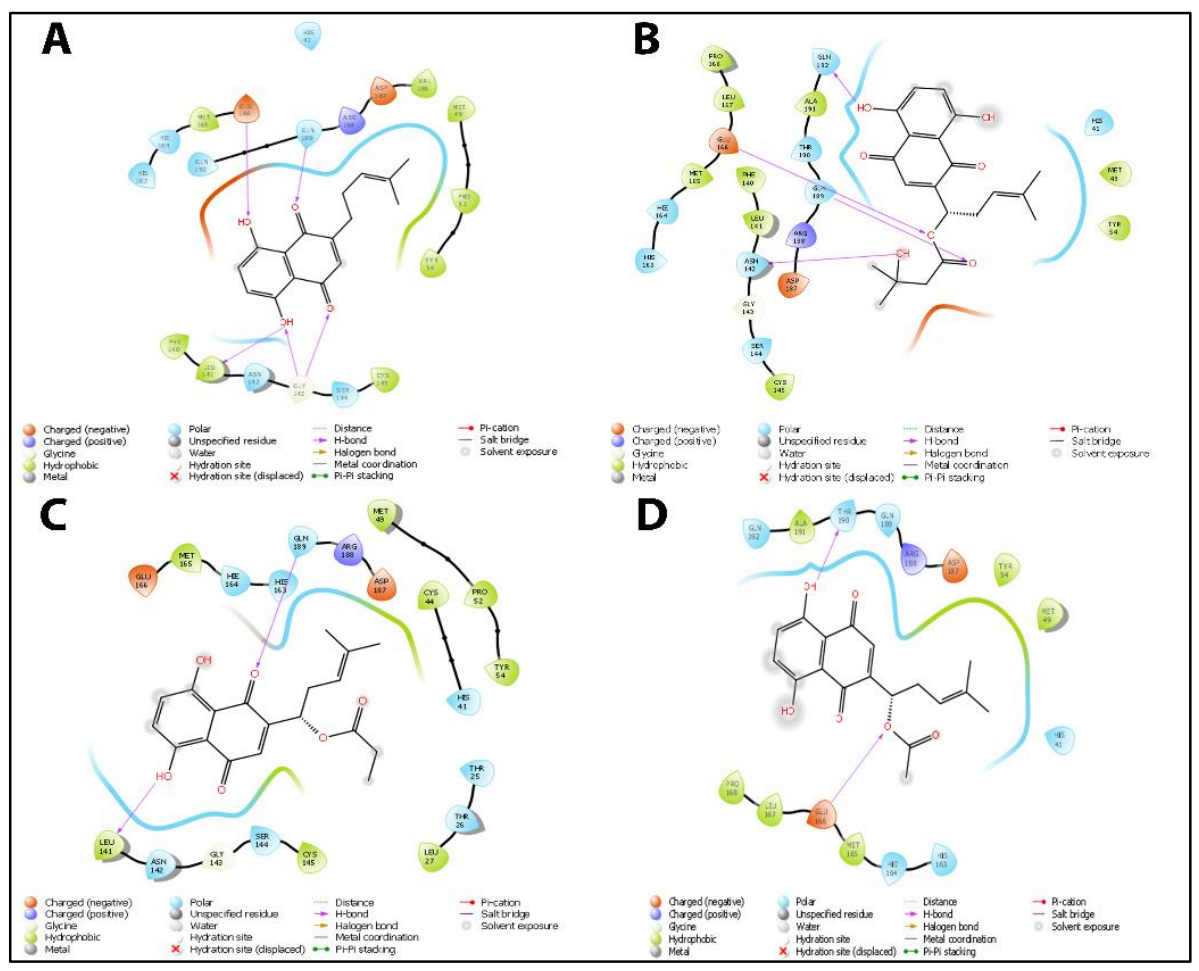

Figure 2. 2D ligand interaction diagrams of deoxyshikonin (A), 3-hydroxy-isovaleryl shikonin (B), propionyl shikonin (C), and acetyl shikonin (D).
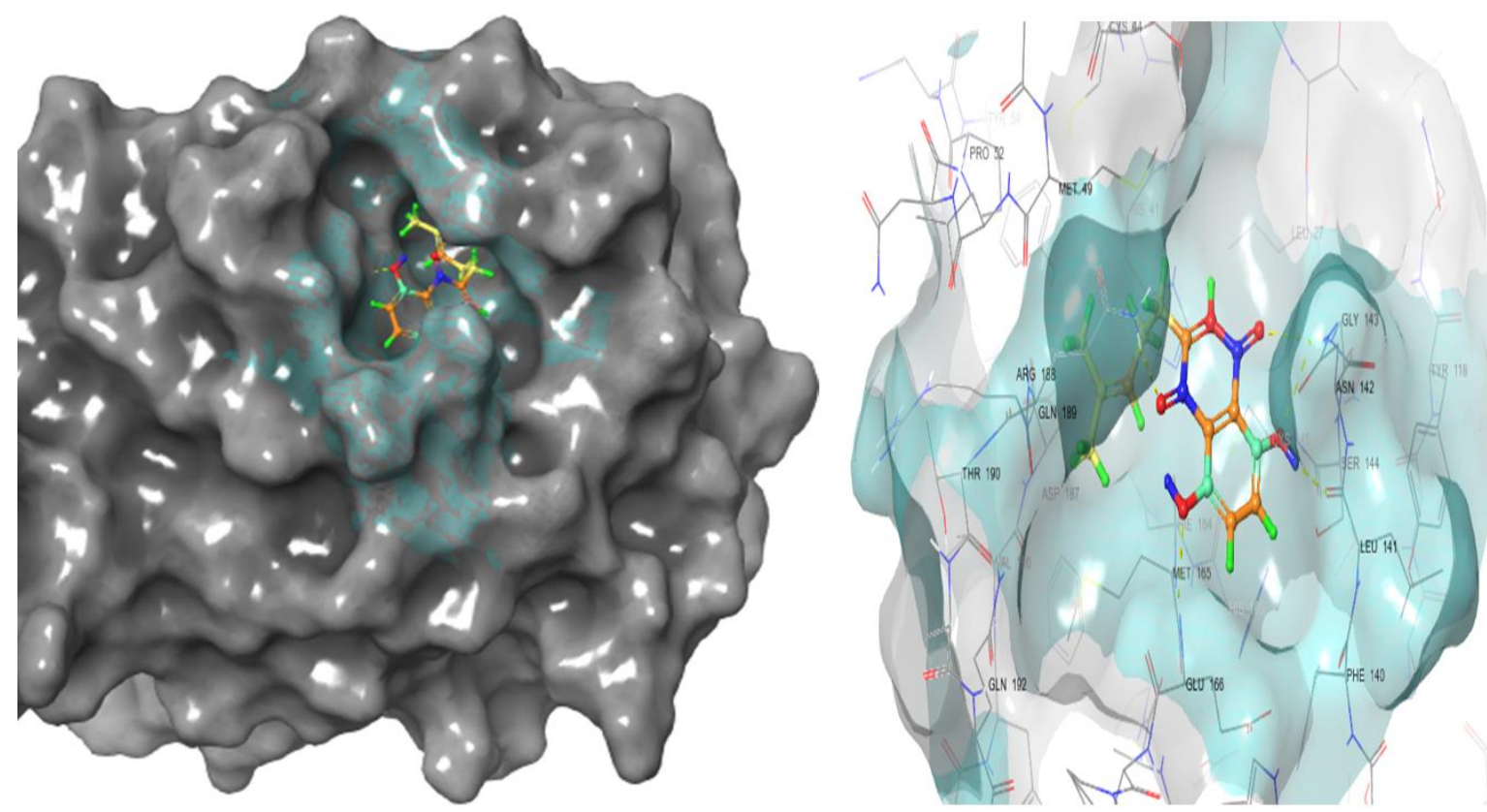

Figure 3. 3D surfaced and 3D detailed binding mode of deoxyshikonin compound. Ligand binding sites of the Mpro enzyme are represented as solid surfaces. 


\section{REFERENCES}

Lillie, P. J., Samson, A., Li, A., Adams, K., Capstick, R., Barlow, G. D., Easom, N., Hamilton, E., Moss, P. J., Evans, A., Ivan, M., Taha, Y., Duncan, C. J. A., \& Schmid, M. L., \& The Airborne HCID Network, PHE Incident Team. (2020). Novel coronavirus disease (Covid-19): The first two patients in the UK with person to person transmission. Journal of Infection, 80, 578-606. https://doi.org/10.1016/j.jinf.2020.02.020

Lai, C. C., Liu, Y. H., Wang, C. Y., Wang, Y. H., Hsueh, S. C., Yen, M. Y., Chien Ko, W., \& Hsueh, P. R. (2020). Asymptomatic carrier state, acute respiratory disease, and pneumonia due to severe acute respiratory syndrome coronavirus 2 (SARS-CoV-2): Facts and myths. Journal of Microbiology, Immunology and Infection, 53(3), 404-412. https://doi.org/10.1016/i.jmii.2020.02.012

De Wit, E., Van Doremalen, N., Falzarano, D., \& Munster, V. J. (2016). SARS and MERS: recent insights into emerging coronaviruses. Nature Reviews Microbiology, 14(8), 523-534. https://doi.org/10.1038/nrmicro.2016.81

Wu, J. T., Leung, K., \& Leung, G. M. (2020). Nowcasting and forecasting the potential domestic and international spread of the 2019-nCoV outbreak originating in Wuhan, China: a modelling study. The Lancet, 395(10225), 689-697. https://doi.org/10.1016/S0140-6736(20)30260-9

Yan, S., Sun, H., Bu, X., \& Wan, G. (2020). New strategy for COVID-19: an evolutionary role for RGD motif in SARSCoV-2 and potential inhibitors for virus infection. Frontiers in Pharmacology, 11, 912. https://doi.org/10.3389/fphar.2020.00912

Van Der Hoek, L., Pyrc, K., Jebbink, M. F., Vermeulen-Oost, W., Berkhout, R. J., Wolthers, K. C., \& Berkhout, B. (2004). Identification of a new human coronavirus. Nature medicine, 10(4), 368-373. https://doi.org/10.1038/nm1024

Zheng, J. (2020). SARS-CoV-2: an emerging coronavirus that causes a global threat. International Journal Of Biological Sciences, 16(10), 1678. 10.7150/ijbs.45053

Hilgenfeld, R. (2014). From SARS to MERS: crystallographic studies on coronaviral proteases enable antiviral drug design. The FEBS Journal, 281(18), 4085-4096. https://doi.org/10.1111/febs.12936

Ortega, J. T., Serrano, M. L., Pujol, F. H., \& Rangel, H. R. (2020). Unrevealing sequence and structural features of novel coronavirus using in silico approaches: The main protease as molecular target. EXCLI Journal, 19, 400. http://dx.doi.org/10.17179/excli2020-1189

Jin, Z., Du, X., Xu, Y., Deng, Y., Liu, M., Zhao, Y., \& Yang, H. (2020). Structure of M pro from SARS-CoV-2 and discovery of its inhibitors. Nature, 582(7811), 289-293. https://doi.org/10.1038/s41586-020-2223-y

El-Shazly, A., Abdel-Ghani, A., \& Wink, M. (2003). Pyrrolizidine alkaloids from Onosma arenaria (Boraginaceae). Biochemical Systematics and Ecology, 31(5), 477-485. https://doi.org/10.1016/S0305-1978(02)00177-1

Binzet, R. (2009). Anatomical and palynological investigations on endemic Onosma mersinana Riedl, Binzet \& Orcan. Pakistan Journal of Botany, 41, 503-510.

Ozgen, U., Miloglu, F. D., \& Bulut, G. (2011). Quantitative determination of shikonin derivatives with UV-Vis spectrophotometric methods in the roots of Onosma nigricaule. Reviews in Analytical Chemistry, 30(2), 5963. https://doi.org/10.1515/revac.2011.014 
Kagramanyan, N. S., \& Mnatsakanyan, V. A. (1985). Shikonin and its derivatives from Onosma setosum roots. Armyanskii Khimicheskii Zhurnal, 38(8), 527-8.

Sut, S., Pavela, R., Kolarčik, V., Cappellacci, L., Petrelli, R., Maggi, F., \& Benelli, G. (2017). Identification of Onosma visianii roots extract and purified shikonin derivatives as potential acaricidal agents against Tetranychus urticae. Molecules, 22(6), 1002. https://doi.org/10.3390/molecules22061002

Ozgen, U., Ikbal, M., Hacimuftuoglu, A., Houghton, P. J., Gocer, F., Dogan, H., \& Coskun, M. (2006). Fibroblast growth stimulation by extracts and compounds of Onosma argentatum roots. Journal of Ethnopharmacology, 104(1-2), 100-103. https://doi.org/10.1016/i.jep.2005.08.052

Schrödinger Release 2020-3: Maestro, Schrödinger, LLC, New York, NY, 2020

Kılınç, N. Inhibition profiles and molecular docking studies of antiproliferative agents against aldose reductase enzyme. International Journal of Chemistry and Technology, 5(1), 77-82. https://doi.org/10.32571/ijct.944049

Genheden, S.; Ryde, U. (2015) The MM/PBSA and MM/GBSA methods to estimate ligand-binding affinities. Expert Opinion on Drug Discovery, 10(5), 449-461. https://doi.org/10.1517/17460441.2015.1032936

Oladele, J. O., Ajayi, E. I., Oyeleke, O. M., Oladele, O. T., Olowookere, B. D., Adeniyi, B. M., \& Oladiji, A. T. (2020). A systematic review on COVID-19 pandemic with special emphasis on curative potentials of Nigeria based medicinal plants. Heliyon, e04897. https://doi.org/10.1016/i.heliyon.2020.e04897

Tada, M., Okuno, K., Chiba, K., Ohnishi, E., \& Yoshii, T. (1994). Antiviral diterpenes from Salvia officinalis. Phytochemistry, 35(2), 539-541. https://doi.org/10.1016/S0031-9422(00)94798-8

Koch, C., Reichling, J., Kehm, R., Sharaf, M. M., Zentgraf, H., Schneele, J., \& Schnitzler, P. (2008). Efficacy of anise oil, dwarf-pine oil and chamomile oil against thymidine-kinase-positive and thymidine-kinase-negative herpesviruses. Journal of Pharmacy and Pharmacology, 60(11), 1545-1550. https://doi.org/10.1211/ipp.60.11.0017

Mukhtar, M., Arshad, M., Ahmad, M., Pomerantz, R. J., Wigdahl, B., \& Parveen, Z. (2008). Antiviral potentials of medicinal plants. Virus Research, 131(2), 111-120. https://doi.org/10.1016/i.virusres.2007.09.008

Tan, W. C., Jaganath, I. B., Manikam, R., \& Sekaran, S. D. (2013). Evaluation of antiviral activities of four local Malaysian Phyllanthus species against herpes simplex viruses and possible antiviral target. International Journal of Medical Sciences, 10(13), 1817. 10.7150/ijms.6902

Mikaili, P., Maadirad, S., Moloudizargari, M., Aghajanshakeri, S., \& Sarahroodi, S. (2013). Therapeutic uses and pharmacological properties of garlic, shallot, and their biologically active compounds. Iranian Journal of Basic Medical Sciences, 16(10), 1031.

Theisen, L. L., \& Muller, C. P. (2012). EPs ${ }^{\circledR} 7630$ (Umckaloabo ${ }^{\circledR}$ ), an extract from Pelargonium sidoides roots, exerts anti-influenza virus activity in vitro and in vivo. Antiviral research, 94(2), 147-156. https://doi.org/10.1016/i.antiviral.2012.03.006

Yu, M. S., Lee, J., Lee, J. M., Kim, Y., Chin, Y. W., Jee, J. G., \& Jeong, Y. J. (2012). Identification of myricetin and scutellarein as novel chemical inhibitors of the SARS coronavirus helicase, nsP13. Bioorganic \& Medicinal Chemistry Letters, 22(12), 4049-4054. https://doi.org/10.1016/i.bmcl.2012.04.081 
Zandi, K., Teoh, B. T., Sam, S. S., Wong, P. F., Mustafa, M. R., \& AbuBakar, S. (2012). Novel antiviral activity of baicalein against dengue virus. BMC Complementary And Alternative Medicine, 12(1), 1-9. https://doi.org/10.1186/1472-6882-12-214

Andújar, I., Ríos, J. L., Giner, R. M., \& Recio, M. C. (2013). Pharmacological properties of shikonin-a review of literature since 2002. Planta Medica, 79(18), 1685-1697. 10.1055/s-0033-1350934

Chen, X., Yang, L., Zhang, N., Turpin, J. A., Buckheit, R. W., Osterling, C., \& Howard, O. Z. (2003). Shikonin, a component of Chinese herbal medicine, inhibits chemokine receptor function and suppresses human immunodeficiency virus type 1. Antimicrobial Agents And Chemotherapy, 47(9), 2810-2816. https://doi.org/10.1128/AAC.47.9.2810-2816.2003 